\title{
COMPARATIVE DURABILITY OF CHROME AND VEGETABLE TANNED SOLE LEATHERS
}

\author{
By R. C. Bowker and M. N. V. Geib
}

\begin{abstract}
An investigation to determine primarily the comparative wearing qualities of regetable and chrome tanned sole leathers. Both natural and filled chrome sole leathers were tested in comparison with vegetable leather and information is presented describing the material, the method of making the tests, and the comparative properties as reflected by the wear, chemical, and hygroscopic tests as well as general observations on thickness and area. Related and incidental data are also presented regarding the comparative wear of natural and filled chrome leathers and also the distribution of the chemical constituents in chrome sole leather for different locations on the hide.

The results show that natural and paraffin filled chrome sole leather will wear longer than vegetable leather in a ratio of approximately 2 to 1 . It is also shown that by using a mineral filler, such as barytes, the wear of the chrome leather is reduced, but is still greater than for vegetable leather.
\end{abstract}

\section{CONTENTS}

I. Introduction

II. Chrome and regetable sole leathers

1. General comparison of properties._- 268

2. Description of leather tested

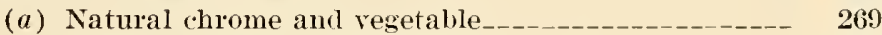

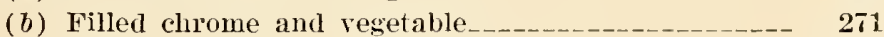

(c) Natural chrome and filled chrome_-____-___-- 273

3. Acknowledgment _- 274

III. Methods

1. Wear tests _._._. 275

(a) Preparation of leather. 275

(b) Test procedure

2. Chemical tests _-_- 275

3. Moisture absorption tests._- 277

4. General observations_... 278

IV. Result

1. Wear tests_______ $27 \mathrm{~S}$

2. Chemical tests_-_- 279

(a) General _. 279

(b) Filling materials__-_-___ 281

3. Moisture absorption tests__- 282

4. General observations _-

(a) Beharior in service

(b) Comparative thickncss_____ 284

(c) Comparative areas ... 285

V. Conclusions 


\section{INTRODUCTION}

Marked success has attended the application of the chrome process of tanning in the manufacture of shoe upper leathers with its consequent economic adrantage in enabling more rapid production while at the same time producing leather lighter in weight, more resistant to the deteriorating action of moisture and acids, less susceptible to cracking, and, in certain cases where the external service conditions are severe, more durable than leather's manufactured by the use of vegetable tanning materials. Regardless of whether the average wear of a chrome-tanned upper leather is greater than that of regetable-tanned upper leather, it is common for the uppers of a pair of shoes to outwear two or three pairs of regetable-tanned soles. The logical aim, then, for maximum service and economy is to produce a sole which will wear as long as the uppers.

Guided by the success of the chrome-tanned upper leather and by a desire to produce a longer wearing sole the chrome process of tanning has been applied to heavy hides in the belief that a product would be obtained superior to the vegetable-tanned leather. Frequent claims that chrome-tanned sole leather would wear two or three times as long as vegetable tanned, a realization of the economic advantage of securing such a soling material, and the lack of any generally available data on the subject, caused this investigation to be undertaken to determine the comparative durability of the two leathers, the results of which are presented in this publication.

\section{CHROME AND VEGETABLE SOLE LEATHERS}

\section{GENERAL COMPARISON OF PROPERTIES}

A comparison of the properties of clirome and regetable sole leathers reveals marked differences which may be attributed to the methods and materials used in their manufacture. In the case of vegetable leather, the hides are treated with vegetable materials containing tamins which slowly combine with the fibers, causing them to swell and have a tendency to fill the interfibrillar spaces. The resulting leather is firm, hard, well filled, and, in a measure, water resistant.

In the manufacture of chrome sole leather the hides are treated with basic chromium salt solutions and there occurs a rapid combination of the chromium and the hide fibers without the degree of swelling occurring in the vegetable process. Consequently the interfibrillar spaces are not closed to such an extent and leather is produced which, by comparison with the vegetable, is pliable, loose in structure. not water resistant, and feels empty. 
A microscopic examination of leathers tanned by the two processes ably serves as a means for showing the differences in the properties mentioned above. Cross sections of both regetable and chrome tanned leather from a steer hide and chrome-tanned leather from a water-buffalo hide were prepared $40 \mu$ in thickness and mounted on slides. The slides were placed in the microscope, through which they were photographed by means of transmitted light at a magnification of 35 diameters.

A comparison of the photomicrographs of the vegetable and chrome tanned leathers from the steer hide (figs. 1 and 2, respectively) shows the larger fibers and fuller appearance of the vegetable leather, while the thimner fibers and empty appearance of the chrome leather are also evident. The photomicrograph of the chrome-tanned buffalo hide (fig. 3) exhibits the same empty appearance, and also shows the larger size of the fibers as compared with those of the chrome-tanned steer hide.

Another noticeable difference between nearly all chrome and vegetable leathers is in their chemical composition. Natural chrome leather as compared with regetable leather is characterized by high content of protein (original hide substance) and mineral matter, and by low content of water soluble materials.

A further characteristic of the chrome method of tanning is evidenced by examining leather tanned from the same hide by both the regetable and chrome processes. 'The chrome leather will be found to have less area and thickness than the regetable leather.

In finishing the natural chrome leather for shoe soles it is necessary for the tanner to fill the leather with certain materials in order to obtain the thickness, firmness, and water-resistant characteristics of corresponding regetable tanned leather. By contrast with this, in finishing the latter leatner processes are employed to accomplish a lessening of the firmness by the addition of softening or hygroscopic materials which hold sufficient moisture in the leather to keep it in the desired mellow condition.

\section{DESCRIPTION OF LEATHER TESTED}

In selecting the different chrome leathers used in these tests typical commercial material was obtained representing natural and filled chrome made from both stecr and buffalo hides. Six series of tests were conducted in making comparisons as to the durability of natural chrome and regetable leathers, filled chrome and regetable leathers, and natural chrome and filled chrome leathers. I general description of the leathers used follows:

(a) Nateral Chrome and Vegemale-One steer hide was prepared for tanning in the usual manner and then cut down the back 
into two sides. One side was tanned by the one-bath chrome process using sodium dichromate as the base and the other side was tanned

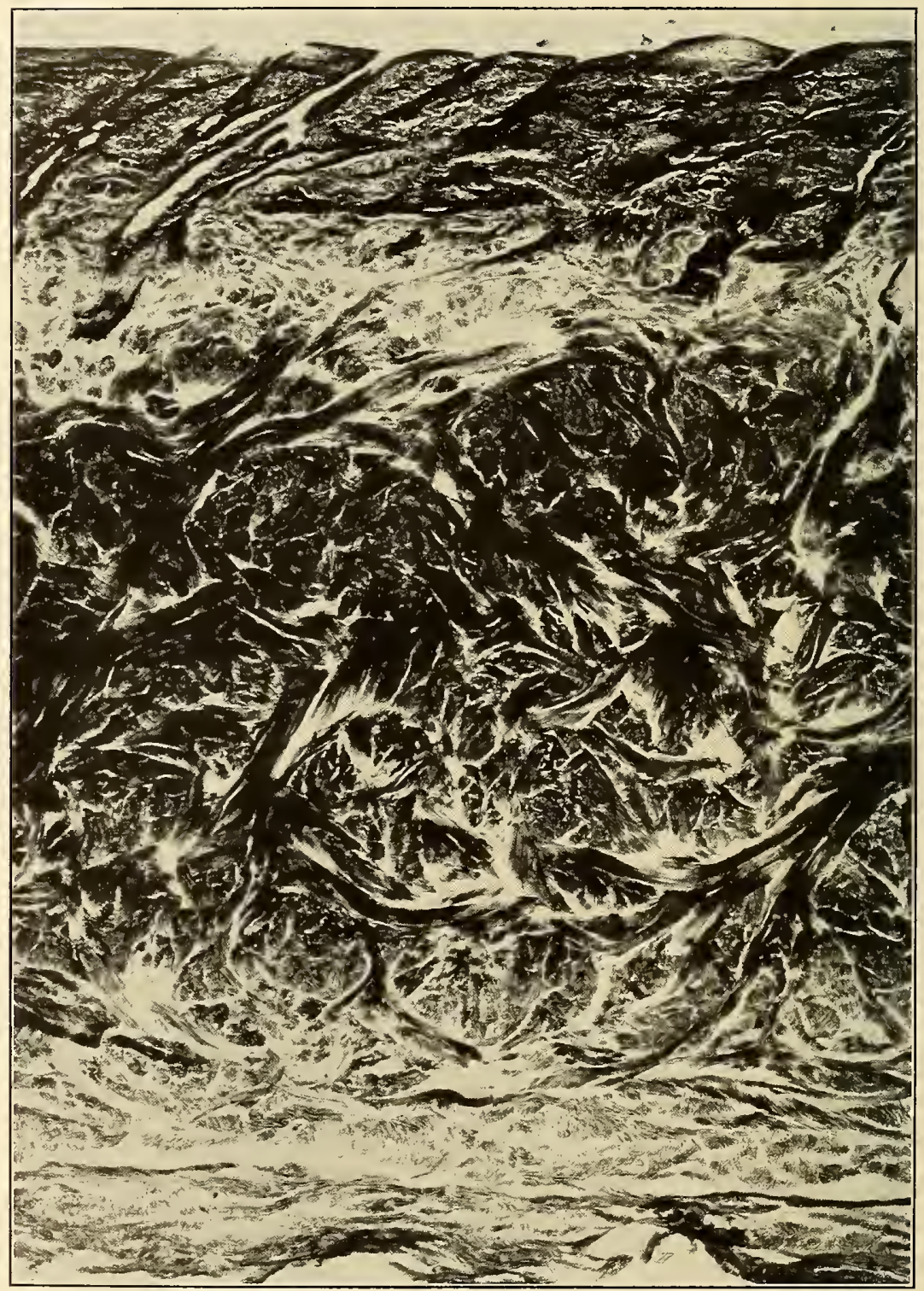

FIG. 1.-Cross scetion of vegetable tanned sole leather from steer hide

by the vegetable process using a blend of liquors made from hemlock bark, chestnut wood, wattle bark, and quebracho. This leather was used in series 2 and is illustrated in Figure 4. 
(b) Filled Chrome and Vegetable.-In series 1, three chrome tanned steer hide bends filled with greases and mineral fillers were tested against three regetable tanned steer hide bends representing a good grade of finder's leather. In series 3 , six hides were prepared for tanning in the usual manner and the heads and bellies were

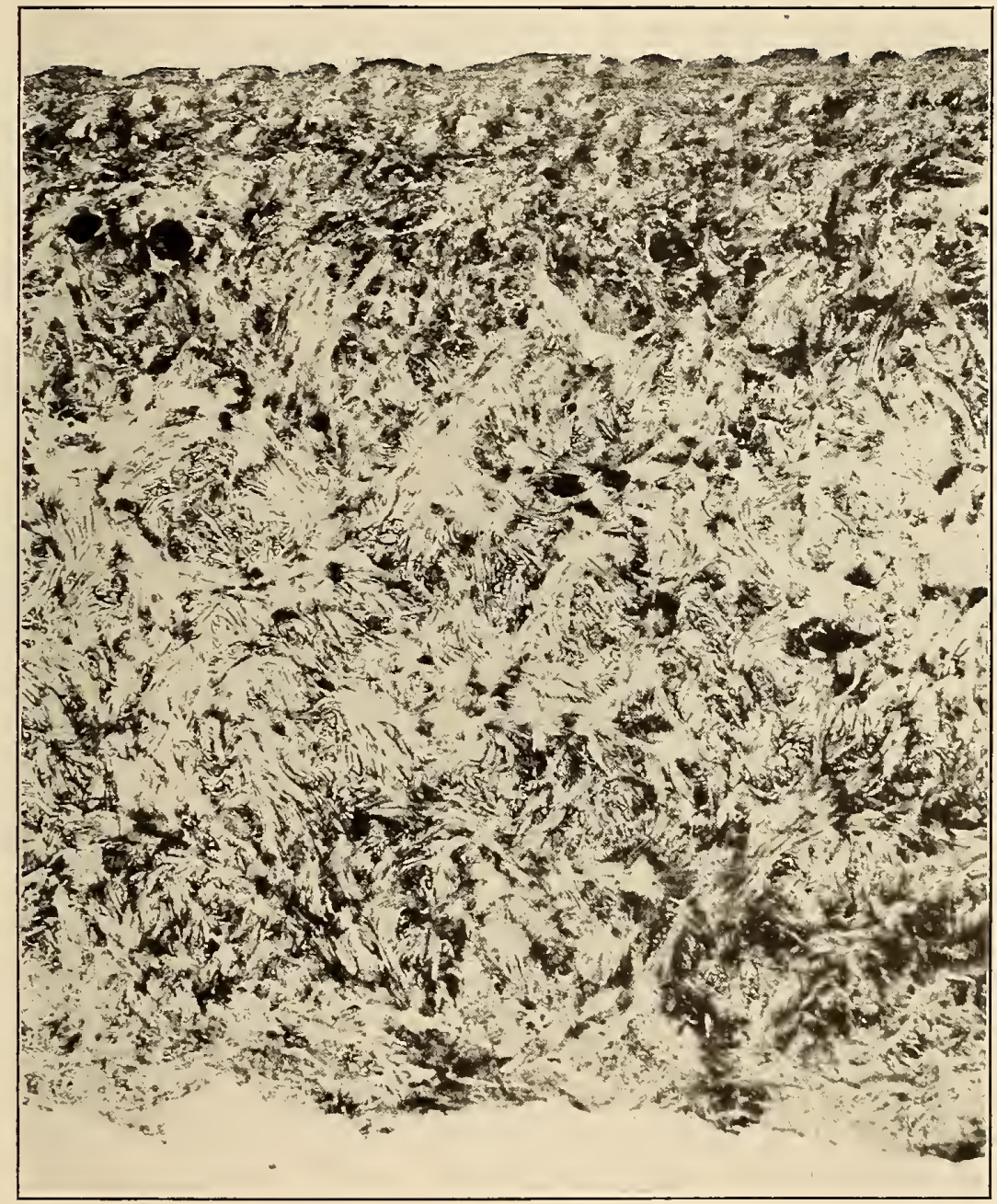

FIG. 2.-Cross section of chrome tanned sole leather from ster hide

trimmed off, after which each hide was cut down the backbone into two backs. Six backs were tanned by the chrome process and filled as was the leather in series 1 . The other six backs were tamed by the regetable process. The plysical appearance of the leather used in series 3 is shown in Figure 5, which represents the leather 
from one of the six hides. In all the previous series steer hide leather was used, and since chrome tanned leather made from buffalo hides is a commercial product it was desired to test this leather in

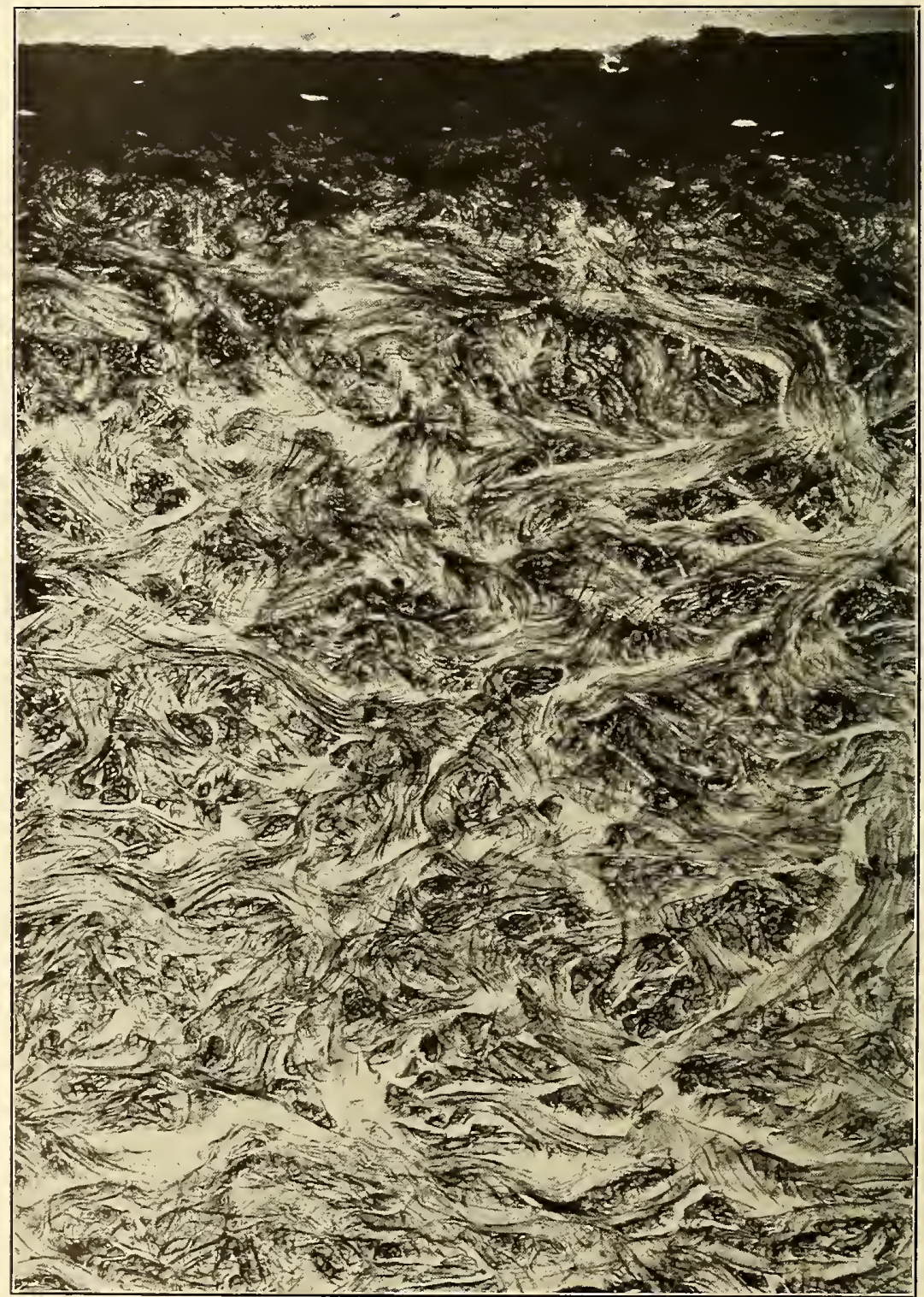

FIg. 3.-Cross seetion of ehrome tanned sole leather from water buffalo hide

comparison with commercial vegetable tanned material, which was made from steer hides. Accordingly in series 4 the leather from three chrome tanned buffalo hide bends was compared with the 
leather from three regetable-tanned steer hide bends the chrome leather being filled with paraffin and cellulose.

(c) Natural Cinrome and Filled Cimrome. - In order to determine the effect on the wearing quality of filling chrome sole leather with paraffin, two series of tests were made by comparing the natural chrome with filled chrome. In series 5 the leather from three

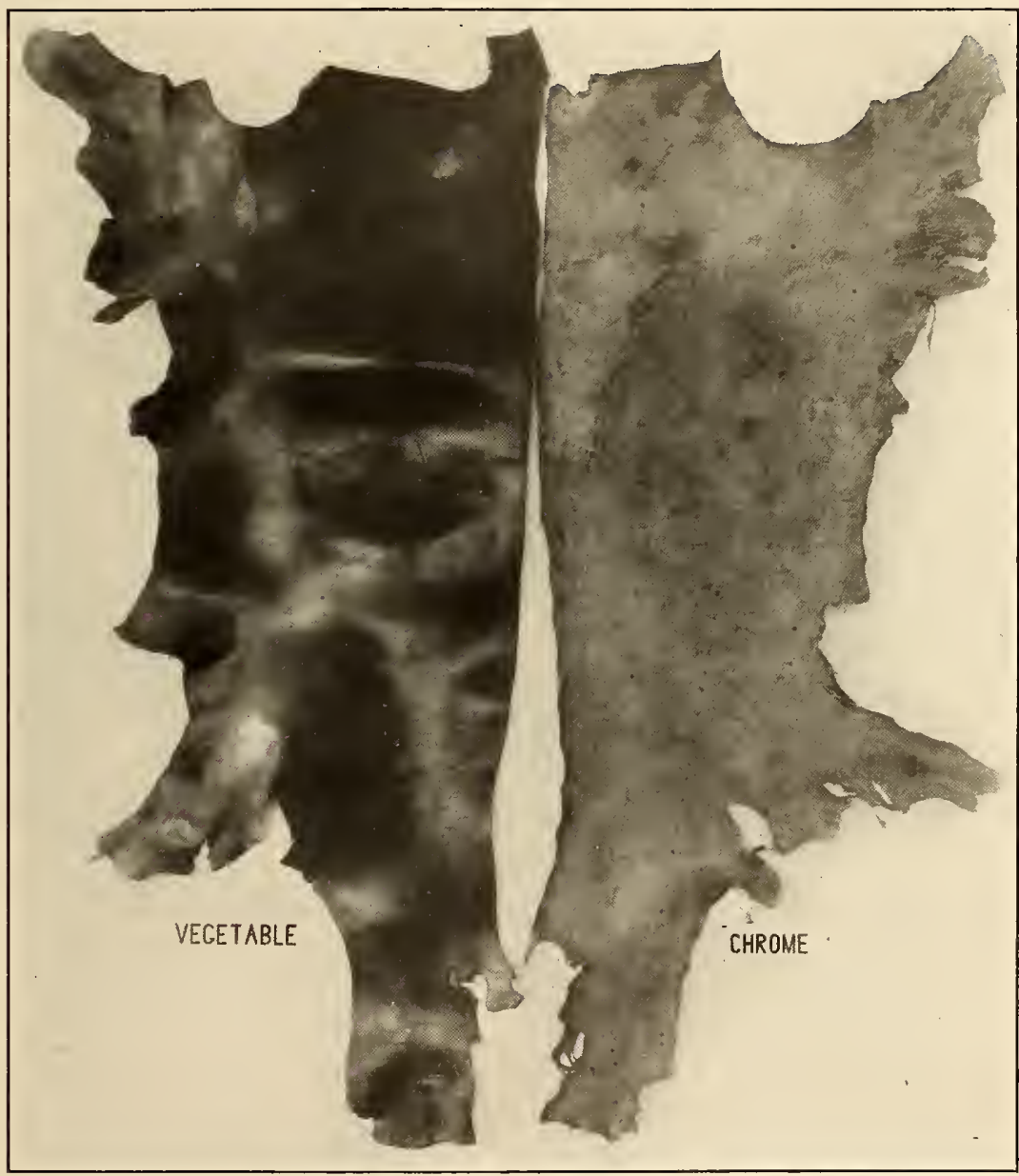

Fic. 4.-Chrome and regetable tanned sole louther used in series 2. Tumed from same hide

natural chrome bends was compared with the leather from three chrome tanned bends filled with paraflin and cellulose. Both chrome leathers were from buffalo hides as was the chrome leather used in series 4 . In series 6 the same comparison was made on thicker chrome leather from buffalo hides the filled leather containing paraffin alone as a filler.

$31099^{\circ}-25-2$ 


\section{ACKNOWLEDGMENT}

In connection with this investigation it is desired to acknowledge the cooperation shown by the tanners and shoe manufacturers who furnished the leathers for this work.

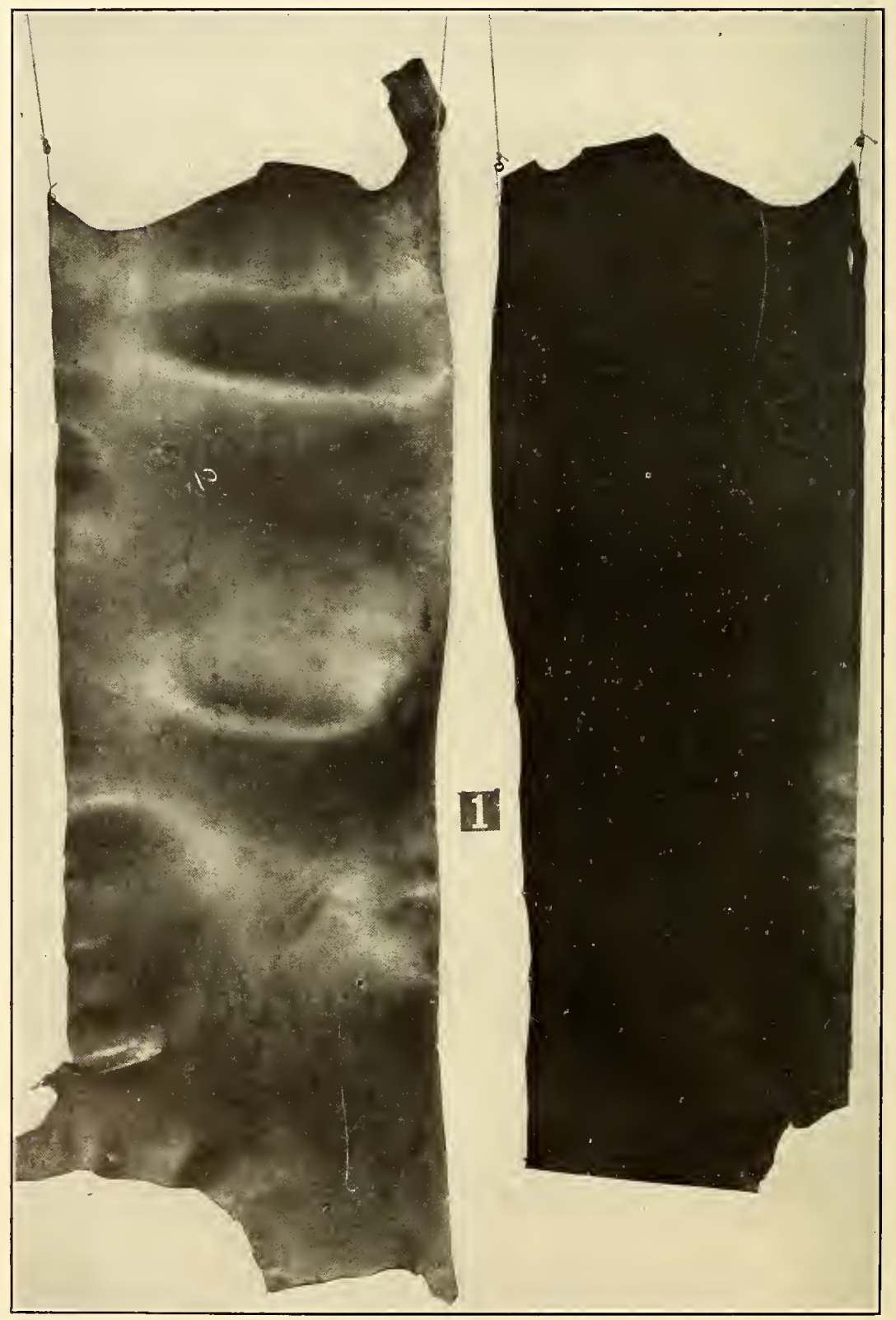

FIg. 5.-C'hrome and vegetable leather used in series 3. Tunned from hide No. 1 


\section{METHODS}

\section{WEAR TESTS}

(a) Preparation of Leatizr.-The leathers tested were received in the form of sides, backs, and bends, but tests were made and reported only on soles cut from the bend portions. The soles were died out, marked as to location on the hide, skived to uniform thickness, measured for thickness in irons and applied to shoes for wear tests. This work was done in the laboratory provided for the preparation of leather samples for physical tests, a view of which is shown in Figure 6.

The manner in which the soles were cut with respect to number and location on the hide is shown in Figure 7, which represents the leather used in series 2. This method is representative for all the units tested. It will be observed that the soles were cut alternately for left and right shoes and that the two soles for any indiridual wear test were so marked as to insure their being located in similar positions on the hide.

(b) Test Procedrre.- The pairs of test soles were attached to men's shoes and worn by laboratory workers, office workers, electricians, plumbers, machinists, firemen, and outside laborer's. A regular system of weekly reports was required from each individual stating the days worn and the type of service. A weekly inspection of each pair was made to note the extent of wear and to secure general information regarding the behavior of the leather in service. In cases where the regetable sole wore out first and there was sufficient wear left in the chrome sole to warrant it, another regetable sole was attached in order to secure the actual time under service conditions required for the chrome sole to wear through. In cases where this procedure ras not feasible and a sole was not worn completely through, the thickness worn aray was determined, from which, with the days worn and the original thickness, the total probable length of rear was computed by proportion.

\section{CHEMICAL TESTS}

In preparing samples for the chemical tests the serap remaining after the soles were cut from all the units of a particular leather rere assembled into a composite sample. An exception to this occurred in the case of the filled chrome leather used in series 3 and the natural chrome leather used in series 5, in which instances the scrap from the corresponding locations on each of the bends was assembled into a composite sample for analysis in order to secure information regarding the distribution of the chemical con- 


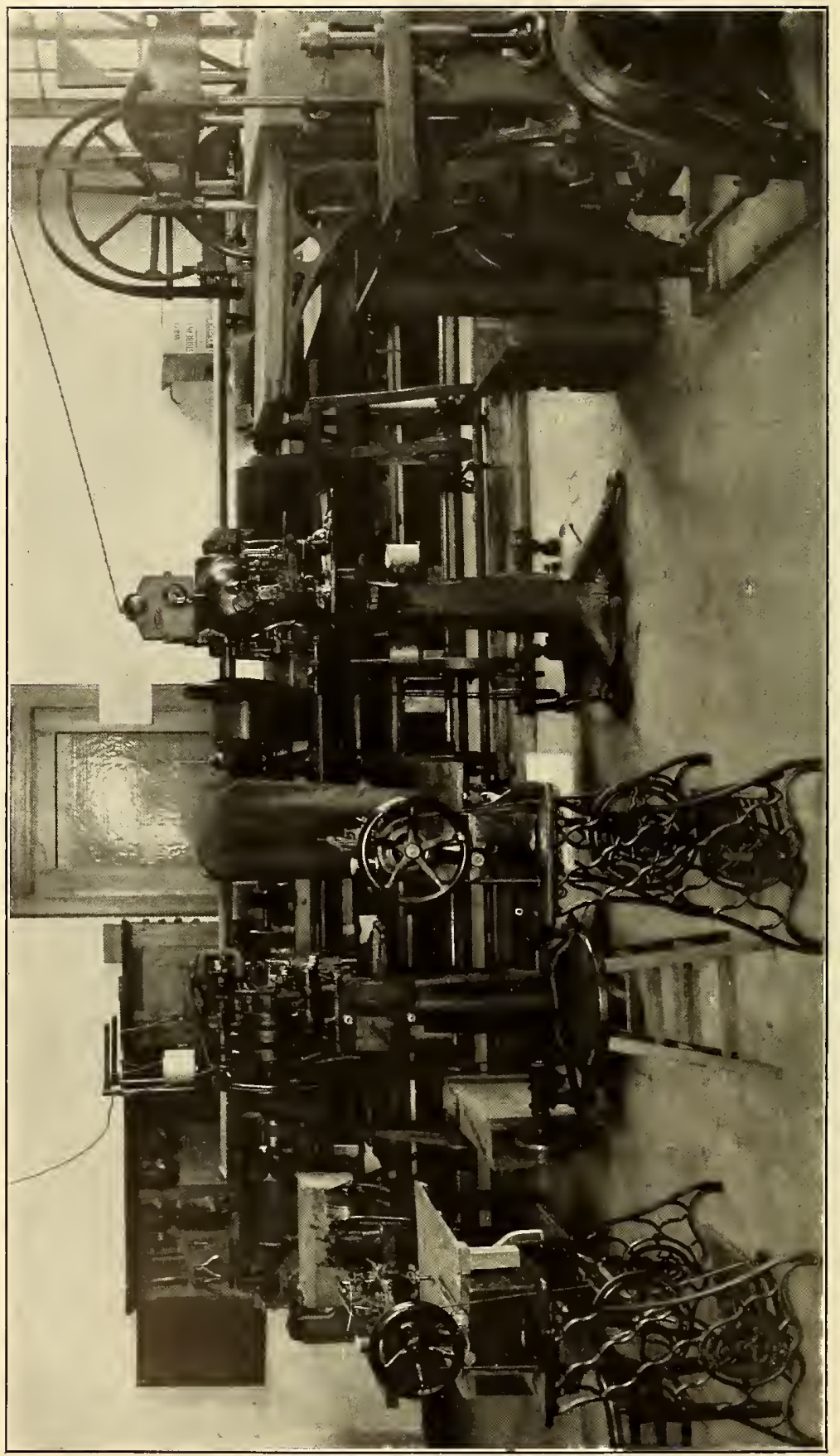

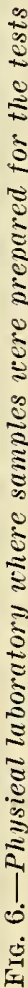


stituents orer the hide area, as had been done previously for vegetable tanned sole leather. ${ }^{1}$

In connection with the chemical analyses special attention was giren to the identification of the filling materials used in the filled chrome leathers.

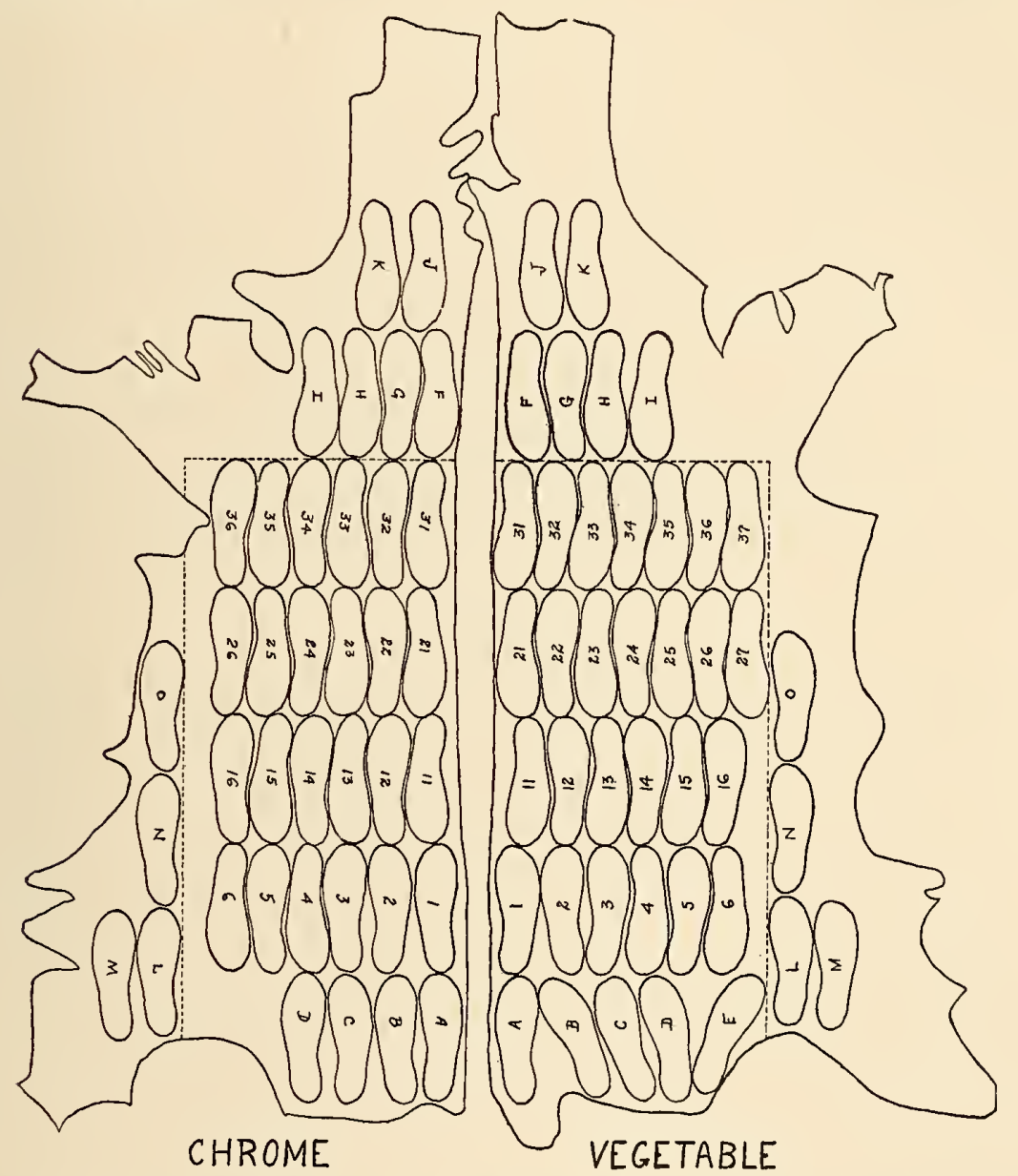

FIG. 7.-Locations on the sides from which soles wore cut and matcled for test in scries 2

\section{MOISTURE ABSORPTION TESTS}

A typical illustration of the difference in moisture absorption properties of natural chrome and regetable leathers was obtained by placing dry samples in atmospheres of definite relative humidity and noting the percentages of moisture absorbed after the samples had come to approximate equilibrium. Atmospheres of 0.20, to,

\footnotetext{
${ }^{1}$ Bureau of Standards Technical l'aper, No, 138, Effects of Glucose and salts on the Wearing Quality of Sole Leather.
} 
60 , and 80 per cent relative humidity were maintained in laboratory desiccators by means of sulphuric-acid solutions. One hundred per cent relative humidity was maintained by using water in the desiccator. The samples were weighed every few days until the change in weight was so small as to indicate nearly maximum absorption and the percentage absorption calculated.

In order to determine the effectiveness of the fillers used with respect to resistance to water penetration, water-absorption tests were made in cases where chrome leathers were available both in the natural and filled condition (series 5 and 6 ). The procedure consisted in cutting samples 2 inches square from location 12 on the bend, soaking them in water for different periods, again weighing, and then calculating the percentage absorption.

\section{GENERAL OBSERVATIONS}

Certain other observations pertinent to the comparison of the properties of the two leathers were made with respect to behavior in service, thickness, and area. The manner of securing these data will be described under the respective headings in the following paragraphs.

\section{RESULTS}

I. WEAR TESTS

The results of the comparative wearing tests are shown in Table 1. In each of the first four series, where the comparison was between chrome and vegetable leathers, the former had the longer wear both in days wear per sole and in days wear per unit of thickness. The chrome leather used in both series 1 and 3 was prepared in the same manner, and the wear results in comparison with the regetable leather are sufficiently close to show that the nature of the filling materials caused a decrease in the wear as compared with the longer wear obtained from natural chrome (series 2) and that filled with paraffin (series 4). The latter two wore over twice as long as the regetable, while the former two averaged approximately a third longer wear. The results clearly indicate the superiority of the chrome tanned leather as far as wear is concerned, and this is further evidenced by the fact that in a total of 264 tests only 17 showed the vegetable leather wearing longer than the chrome. These 17 tests were divided among series 1 and 3 where the same chrome leather was used. In no test was a natural or paraffin filled chrome sole outworn by its regetable mate.

Series 5 and 6 indicate that the natural chrome will slightly outwear that filled with paraffin. Where the percentage difference is so small, a greater variation in individual tests is expected, and in the total of 147 tests in these two series 90 , or 61 per cent, gare results showing longer wear for the natural chrome leather. 
TABLE 1.-Results of wear tests

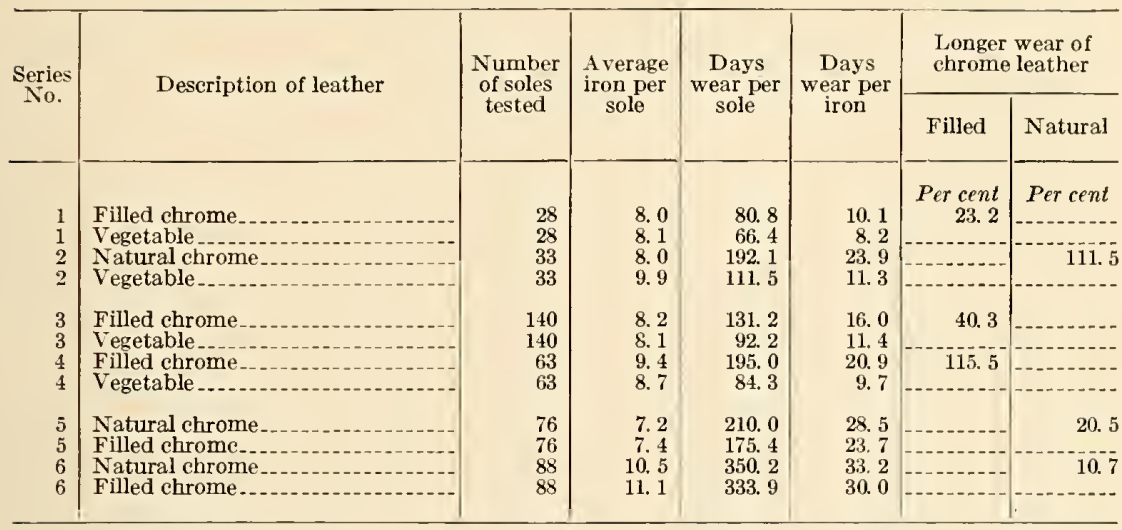

A general summary of the wear-test results shows that under the test conditions which existed chrome leather, regardless of filling treatment, outwore vegetable-tanned leather, the natural chrome giving the longest wear ratio, which decreased according to the types of filling materials used.

\section{CHEMICAL TESTS}

(a) General. - The analyses showing the chemical constituents of each of the leathers tested are shown in Table 2. By comparison with the vegetable leather the analysis for any natural chrome leather shows that the latter is characterized by low water soluble content, low material combined with the hide substance. and consequently high hide substance.

The properties of the two leathers caused by the tannage are, to a certain extent, explained by the difference in the three chemical constituents named. The amount of material combined with the hide during the tanning process is indicated by the combined tannin for the vegetable leathers and by the chromic oxide $\left(\mathrm{Cr}_{2} \mathrm{O}_{3}\right)$ for the chrome leathers. The four vegetable leathers show an average of 28 parts of combined tannin in each 100 parts of leather, while the chrome leathers show an average of 5.6 parts of chromic oxide in each 100 parts of leather. This fact accounts for the greater density or weight of the vegetable leather. The vegetable process of tanning also results in a certain filling of the hide with materials derived from the tanning agents used which come out of the leather when it is treated with water at $50^{\circ} \mathrm{C}$., the temperature at which water soluble determinations are made. The average water soluble content for the four vegetable leathers tested was approximately 25 per cent, while for the chrome leather other than that nsed in series 1 and 3 the percentage varied from 1.60 to 5.55, showing that the chrome process of tanning has little filling action on the hide. 
From the greater amount of material combined with the hide and the greater amount of material in the leather, as shown by the water soluble determination, the greater firmness, solidity, and waterresistant properties of the regetable leather may be explained.

TABLE 2.-Chemical analysis of leathers tested

[On moisture-free basis]

\begin{tabular}{|c|c|c|c|c|c|c|c|c|c|c|c|c|}
\hline \multirow[b]{2}{*}{ Constituent } & \multicolumn{2}{|c|}{ Series 1} & \multicolumn{2}{|c|}{ Series 2} & \multicolumn{2}{|c|}{ Series 3} & \multicolumn{2}{|c|}{ Series 4} & \multicolumn{2}{|c|}{ Series 5} & \multicolumn{2}{|c|}{ Series 6} \\
\hline & 害藏 & 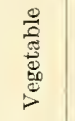 & 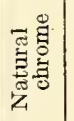 & 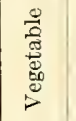 & 열열 & 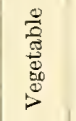 & 䓛章 & 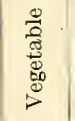 & 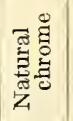 & 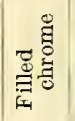 & 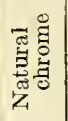 & 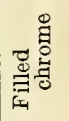 \\
\hline $\begin{array}{l}\text { Water solubles } \\
\text { Hide substance } \\
\text { Grease (P. E. E.) } \\
\text { 'nsoluble ash } \\
\text { Combined tannin } \\
\text { Degree of tannage. }\end{array}$ & $\begin{array}{l}\text { P.ct. } \\
15.18 \\
34.75 \\
22.83 \\
19.47 \\
-\end{array}$ & $\begin{array}{r}P . c t . \\
25.91 \\
41.25 \\
2.27 \\
.15 \\
30.43 \\
74.00\end{array}$ & $\begin{array}{r}P . c t . \\
5.85 \\
74.20 \\
2.73 \\
7.90\end{array}$ & $\begin{array}{r}P . c t \\
29.85 \\
38.36 \\
2.41 \\
.20 \\
29.18 \\
76.00\end{array}$ & \begin{tabular}{l} 
P. ct. \\
12.98 \\
34.61 \\
22.71 \\
\hdashline
\end{tabular} & $\begin{array}{r}P . c t . \\
28.45 \\
39.51 \\
3.24 \\
.50 \\
28.30 \\
72.00\end{array}$ & P.ct. & $\begin{array}{l}P . c t . \\
\left\{\begin{array}{r}31.88 \\
37.67 \\
3.46 \\
.42 \\
26.57 \\
71.00\end{array}\right.\end{array}$ & $\begin{array}{r}P . c t . \\
4.64 \\
80.55 \\
1.79\end{array}$ & $\begin{array}{l}\text { P.ct. } \\
23.12\end{array}$ & $\begin{array}{r}P . c t . \\
1.68 \\
88.15 \\
1.00 \\
6.73 \\
---\end{array}$ & $\begin{array}{r}\text { P. ct. } \\
1.60 \\
64.35 \\
24.07 \\
6.04 \\
-\end{array}$ \\
\hline $\begin{array}{l}\text { Glucose } \\
\text { Epsom salts }\end{array}$ & 6. 03 & $\begin{array}{r}3.64 \\
.50\end{array}$ & & $\begin{array}{l}7.18 \\
2.17 \\
27\end{array}$ & 5. 54 & $\begin{array}{l}3.80 \\
3.42\end{array}$ & & $(4.66$ & & & & \\
\hline $\begin{array}{l}\text { Aclal ash } \\
\text { Total ash } \\
\mathrm{Cr}_{2} \mathrm{O}_{3} \text { (fat free) }\end{array}$ & $\begin{array}{r}20.18 \\
5.08\end{array}$ & .42 & $\begin{array}{l}9.87 \\
7.22\end{array}$ & .99 & $\begin{array}{r}23.19 \\
4.06\end{array}$ & 2.76 & $\cdots$ & 2.80 & $\begin{array}{r}8.00 \\
5.24\end{array}$ & - & $\begin{array}{l}6.75 \\
5.55\end{array}$ & $\begin{array}{l}6.08 \\
6.23\end{array}$ \\
\hline
\end{tabular}

${ }^{1}$ Same as leather used in series 5.

From the above discussion it logically follows that the chrome leather will have a higher percentage of hide substance. The average value for the natural chrome leathers in series 2,5 , and 6 was 81 per cent, which value is about double the amount in any of the vegetable leathers. Since hide substance is the chief raw material from which leather derives its durability it might logically be expected that the ratio of the wear within broad limits would conform to the ratio of hide substance. From the results of the wear tests in series 2, where both leathers were tanned from the same hide, the chrome leather is shown to have worn approximately 100 per cent longer than the regetable. In comparing the hide substance figures for these two leathers (74.2 per cent for the chrome and 38.4 per cent for the regetable) it will be seen that the chrome leather had approximately 100 per cent more than the regetable. Where the character of the natural chrome leather is changed by the addition of filling materials this correlation does not hold, since the chrome leather in series 1 and 3 had less hide substance than the vegetable, but wore approximately one-third longer. It would be expected that both these leathers in their natural condition would wear 100 per cent longer than the vegetable, but in these tests this property was apparently decreased by the addition of the mineral filler to secure permanent firmness. While 23 per cent of grease was also added to these chrome leathers, it is shown in series 4,5 , and 6 that the addi- 
tion of grease alone does not greatly affect the wearing quality of the chrome leather.

TABLE 3.-Chemical analyses of natural and filled chrome leathers for different locations on the bend

[On moisture-free basis]

\begin{tabular}{|c|c|c|c|c|c|c|c|c|c|c|}
\hline \multirow[b]{2}{*}{ Location or hide } & \multicolumn{5}{|c|}{ Natural chrome used in series 4} & \multicolumn{5}{|c|}{ Filled chrome used in series 3} \\
\hline & $\begin{array}{c}\text { Water } \\
\text { solubles }\end{array}$ & $\begin{array}{l}\text { Hide } \\
\text { sub- } \\
\text { stance }\end{array}$ & $\begin{array}{l}\text { Grease } \\
\text { P.E.E. }\end{array}$ & $\begin{array}{c}\text { Total } \\
\text { ash }\end{array}$ & $\mathrm{Cr}_{2} \mathrm{O}_{3}$ & $\begin{array}{c}\text { Water } \\
\text { solubles }\end{array}$ & $\begin{array}{l}\text { Hide } \\
\text { sub- } \\
\text { stance }\end{array}$ & $\begin{array}{c}\text { Grease } \\
\text { P.E.E. }\end{array}$ & $\begin{array}{l}\text { Total } \\
\text { ash }\end{array}$ & $\mathrm{Cr}_{2} \mathrm{O}_{3}$ \\
\hline $\begin{array}{l}1 \\
2 \\
3 \\
4 \\
5 \\
6\end{array}$ & $\begin{array}{c}\text { Per cent } \\
4.52 \\
4.85 \\
4.88 \\
4.75 \\
3.40 \\
5.11\end{array}$ & $\begin{array}{c}\text { Per cent } \\
78.21 \\
82.10 \\
83.31 \\
83.87 \\
83.61 \\
79.68\end{array}$ & $\begin{array}{c}\text { Per cent } \\
3.08 \\
1.48 \\
1.26 \\
1.26 \\
1.05 \\
2.75\end{array}$ & \begin{tabular}{|} 
Per cent \\
8.84 \\
8.18 \\
8.36 \\
7.88 \\
7.73 \\
9.19
\end{tabular} & $\begin{array}{c}\text { Per cent } \\
4.81 \\
5.15 \\
5.10 \\
4.99 \\
5.48 \\
4.90\end{array}$ & $\begin{array}{c}\text { Per cent } \\
13.42 \\
12.52 \\
13.08 \\
12.67 \\
13.42 \\
13.63\end{array}$ & $\begin{array}{c}\text { Per cent } \\
32.31 \\
34.21 \\
35.33 \\
35.68 \\
33.41 \\
31.90\end{array}$ & $\begin{array}{c}\text { Per cent } \\
23.60 \\
23.50 \\
22.82 \\
22.72 \\
21.51 \\
21.83\end{array}$ & \begin{tabular}{|c|} 
Per cent \\
23.93 \\
23.31 \\
23.09 \\
23.29 \\
23.97 \\
24.48
\end{tabular} & $\begin{array}{r}\text { Per cent } \\
3.24 \\
3.32 \\
3.65 \\
3.57 \\
3.42 \\
3.31\end{array}$ \\
\hline 13 & $\begin{array}{l}4.95 \\
\text { 4. } 33 \\
\text { 4. } 21 \\
4.46 \\
\text { 4. } 87 \\
\text { 5. } 54\end{array}$ & $\begin{array}{l}83.64 \\
81.61 \\
80.86 \\
78.44 \\
81.38 \\
77.01\end{array}$ & $\begin{array}{l}2.26 \\
1.72 \\
1.13 \\
1.04 \\
1.37 \\
2.35\end{array}$ & $\begin{array}{l}8.09 \\
7.69 \\
7.52 \\
7.65 \\
7.56 \\
9.32\end{array}$ & $\begin{array}{l}\text { 5. } 35 \\
\text { 4. } 94 \\
5.11 \\
5.04 \\
4.89 \\
5.61\end{array}$ & $\begin{array}{l}13.80 \\
12.55 \\
13.09 \\
13.02 \\
14.55 \\
13.08\end{array}$ & $\begin{array}{l}33.81 \\
36.25 \\
36.89 \\
35.48 \\
34.58 \\
34.23\end{array}$ & $\begin{array}{l}23.55 \\
23.67 \\
23.71 \\
24.12 \\
23.16 \\
21.78\end{array}$ & $\begin{array}{l}22.23 \\
21.28 \\
21.64 \\
21.64 \\
22.52 \\
23.98\end{array}$ & $\begin{array}{l}3.11 \\
2.93 \\
3.32 \\
\text { 3. } 41 \\
3.37 \\
\text { 3. } 18\end{array}$ \\
\hline $\begin{array}{l}21 \\
22 \\
23 \\
24 \\
25 \\
26\end{array}$ & $\begin{array}{l}5.18 \\
4.38 \\
4.69 \\
4.38 \\
4.16 \\
4.15\end{array}$ & $\begin{array}{l}76.66 \\
80.87 \\
81.44 \\
82.77 \\
79.23 \\
79.56\end{array}$ & $\begin{array}{l}2.99 \\
1.64 \\
1.65 \\
1.58 \\
1.07 \\
1.91\end{array}$ & $\begin{array}{l}8.84 \\
7.65 \\
7.64 \\
7.87 \\
7.31 \\
7.19\end{array}$ & $\begin{array}{l}5.36 \\
5.11 \\
5.18 \\
5.05 \\
5.33 \\
5.39\end{array}$ & $\begin{array}{l}12.52 \\
11.76 \\
12.52 \\
12.74 \\
12.81 \\
12.63\end{array}$ & $\begin{array}{l}35.37 \\
34.63 \\
36.02 \\
35.77 \\
34.88 \\
33.89\end{array}$ & $\begin{array}{l}24.77 \\
24.28 \\
23.50 \\
23.60 \\
23.08 \\
20.94\end{array}$ & $\begin{array}{l}21.92 \\
22.16 \\
21.87 \\
22.97 \\
23.70 \\
24.03\end{array}$ & $\begin{array}{l}3.00 \\
3.28 \\
3.50 \\
2.74 \\
3.16 \\
3.48\end{array}$ \\
\hline $\begin{array}{l}31 \ldots \\
32 \ldots \\
33 \ldots \\
34 \ldots \\
35 \ldots \\
36 \ldots\end{array}$ & $\begin{array}{l}4.61 \\
4.87 \\
4.88 \\
4.06 \\
5.13 \\
5.02\end{array}$ & $\begin{array}{l}77.76 \\
80.22 \\
80.73 \\
81.27 \\
80.16 \\
78.74\end{array}$ & $\begin{array}{l}1.62 \\
1.89 \\
1.79 \\
1.55 \\
1.83 \\
2.61\end{array}$ & $\begin{array}{l}9.36 \\
7.47 \\
7.59 \\
7.80 \\
7.49 \\
7.88\end{array}$ & $\begin{array}{l}5.33 \\
5.08 \\
5.00 \\
5.10 \\
5.18 \\
5.19\end{array}$ & $\begin{array}{l}12.90 \\
12.12 \\
12.41 \\
12.66 \\
12.67 \\
15.24\end{array}$ & $\begin{array}{l}34.42 \\
35.42 \\
35.64 \\
34.49 \\
34.36 \\
31.47\end{array}$ & $\begin{array}{l}22.30 \\
22.29 \\
21.67 \\
21.37 \\
21.73 \\
19.32\end{array}$ & $\begin{array}{l}23.48 \\
22.58 \\
22.97 \\
24.25 \\
23.73 \\
27.85\end{array}$ & $\begin{array}{l}3.10 \\
3.02 \\
2.95 \\
3.18 \\
3.63 \\
3.12\end{array}$ \\
\hline
\end{tabular}

(b) Filumg Matemials.-It has already been pointed out that natural chrome leather by comparison with regetable leather is empty, and consequently is not as firm, as resistant to water penetration, or as thick as the vegetable leather when made from similar hides. In order to approach the degree of these properties characteristic of the latter leather, certain filling materials are used. As reflected by the chemical analyses of the chrome leathers tested, these filling materials were found to be paraffin, cellulose, barium sulphate, hard greases, and glucose.

The filling used in series 6 was paraffin, approximately 25 per cent on the dry weight being added to the leather. Treatment with paraffin is a quick and effective way by which an initially hard and water-resistant leather may be secured which can be applied to the shoe without manufacturing difficulties, and which will take a good edge finish without fraying of the fibers.

In series 4 and 5 paraffin was also used, but it was evident that not all extractable material had been remored with petroleum ether. By extracting with acetone a higher percentage of extractable ma- 
terial was secured, part of which was considered as pyroxylin material. The mixture appeared to be about 4 parts paraffin and 1 part pyroxylin, and the total weight was approximately 25 per cent on the dry leather.

The analyses of the chrome leather used in series 1 and 3 showed hard greases, glucose, and high ash. The latter upon analysis proved to be largely barium sulphate, which was used to secure firmness. The purpose of adding glucose was to utilize its property of taking up moisture in order to keep the leather from being too hard to work satisfactorily. The filling materials in these samples on the dry leather weight were approximately 23 per cent for grease, 6 per

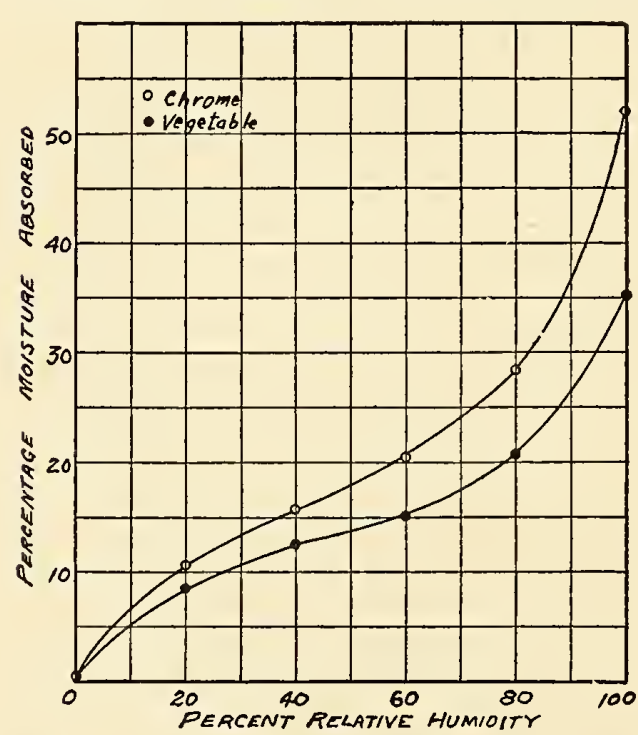

Fig. S.-Effeet of relative humidity on the hygroseopic properties of ehrome and regetable tanned sole leathers. cent for glucose, and 16 per cent for barium sulphate, or a total of 45 per cent.

\section{MOISTURE ABSORPTION TESTS}

The effect of relative humidity on natural chrome and regetable tanned sole leathers is shown in Figure 8. Naturally both leathers show an increasing absorption with increasing relative humidities with the chrome leather absorbing the greater amount at any definite point. The difference in the amount absorbed by the two leathers became greater with increasing humidities, reaching a maximum at 100 per cent where the chrome leather was found to have taken up 52 parts, and the vegetable leather 35.2 parts of moisture per 100 parts of dry leather. These results indicate a decided advantage in favor of vegetable tanned leather, and an attempt is made to offset it by the addition of filling materials to the natural chrome leathers. The results of this test also check very closely with those obtained by Wilson and Gallun ${ }^{2}$ with chrome and regetable tanned calf leathers, which indicates that this difference in hygroscopic properties is a characteristic produced by the types of tannage regardless of the kind of leather.

\footnotetext{
2 Chemistry and comfort, by John Artlur Wilson and A. F. Gallun, jr., Ind. and Eng.
} Chem.; March, 1924. 
The results of the water-absorption tests on the natural and filled chrome sole leathers used in series 5 and 6 are contained in Table 4. The chief filling material in these samples was paraffin.

TABLE 4.- Water absorption tests of chrome sole leather

\begin{tabular}{|c|c|c|c|c|c|}
\hline \multirow{2}{*}{ Series number } & \multirow{2}{*}{ Treatment } & \multicolumn{4}{|c|}{ Absorption on air dry weight- } \\
\hline & & 30 minutes & 1 hour & 24 hours & 8 days \\
\hline $3 .$. & $\left\{\begin{array}{l}\text { Natural } \\
\text { Filled } \\
\text { \{ Natural } \\
\text { Filled }\end{array}\right.$ & $\begin{array}{r}\text { Per cent } \\
11.5 \\
1.7 \\
18.7 \\
2.8\end{array}$ & $\begin{array}{r}\text { Per cent } \\
15.4 \\
2.3 \\
26.9 \\
4.0\end{array}$ & $\begin{array}{r}\text { Per cent } \\
50.6 \\
15.4 \\
72.5 \\
19.4\end{array}$ & $\begin{array}{c}\text { Per cent } \\
39 . \overline{1} \\
43 . \overline{7}\end{array}$ \\
\hline
\end{tabular}

These results clearly show that the fillers acted efficiently in prerenting the rapid absorption of water by the treated leathers, but that the ratio of the amounts absorbed by the natural and its corresponding treated leather decreased with increasing periods of immersion. This implies a tendency for both to reach approximately the same maximum if sufficient time is given the treated leather to do so. An indication that this may be so is shown by the results for the treated leathers after eight days immersion and is confirmatory evidence that the stuffing of leather with grease does not materially affect the ultimate amount of moisture that will be absorbed, but rather retards the rate of absorption.

An interesting observation made during these tests was that, owing to the swelling of the hide fibers during 24 hours' immersion, the natural chrome leathers increased in thickness about 25 per cent and the filled leathers about 11 per cent.

\section{GENERAL OBSERVATIONS}

(a) Behavior in Service.-A summary of the results of the weekly inspections and the comments of the individual wearers led to certain general conclusions regarding the behavior of the chrome sole leather in actual service. The natural chrome leathers became very soft and pliable; had a decided tendency to spread and curl up on the edges; allowed water to penetrate rapidly; frayed on the edges, thus detracting from the shoe's appearance; and slipped readily on smooth, wet objects. The leather filled with paraffin, although very hard when first put on the slioe, soon became pliable, spread, frayed some on the edges, slipped, and after a certain period of wear seemed to lose its water-resistant property, due probably to the working out of the hard paraffin wax by flexing. The leather filled with paraffin and pyroxylin acted in like manner, excepting that it did not fray to such an extent and seemed to retain its waterresistant property longer. Of all the filled leathers, that used in series 1 and 3, which had considerable mineral material added, was superior in all the above-mentioned characteristics and appeared to 
remain as firm and water resistant throughout as the regetable leather.

(b) Comparative Thickness.-A factor to be considered in the production of chrome sole leather is the reduced thickness or iron ${ }^{3}$ obtained as compared with that given by the vegetable tanning process. A good illustration of this difference is offered in the case of the leathers tested in series 2 , since both were tanned from the same hide. The average thickness of the natural chrome soles was

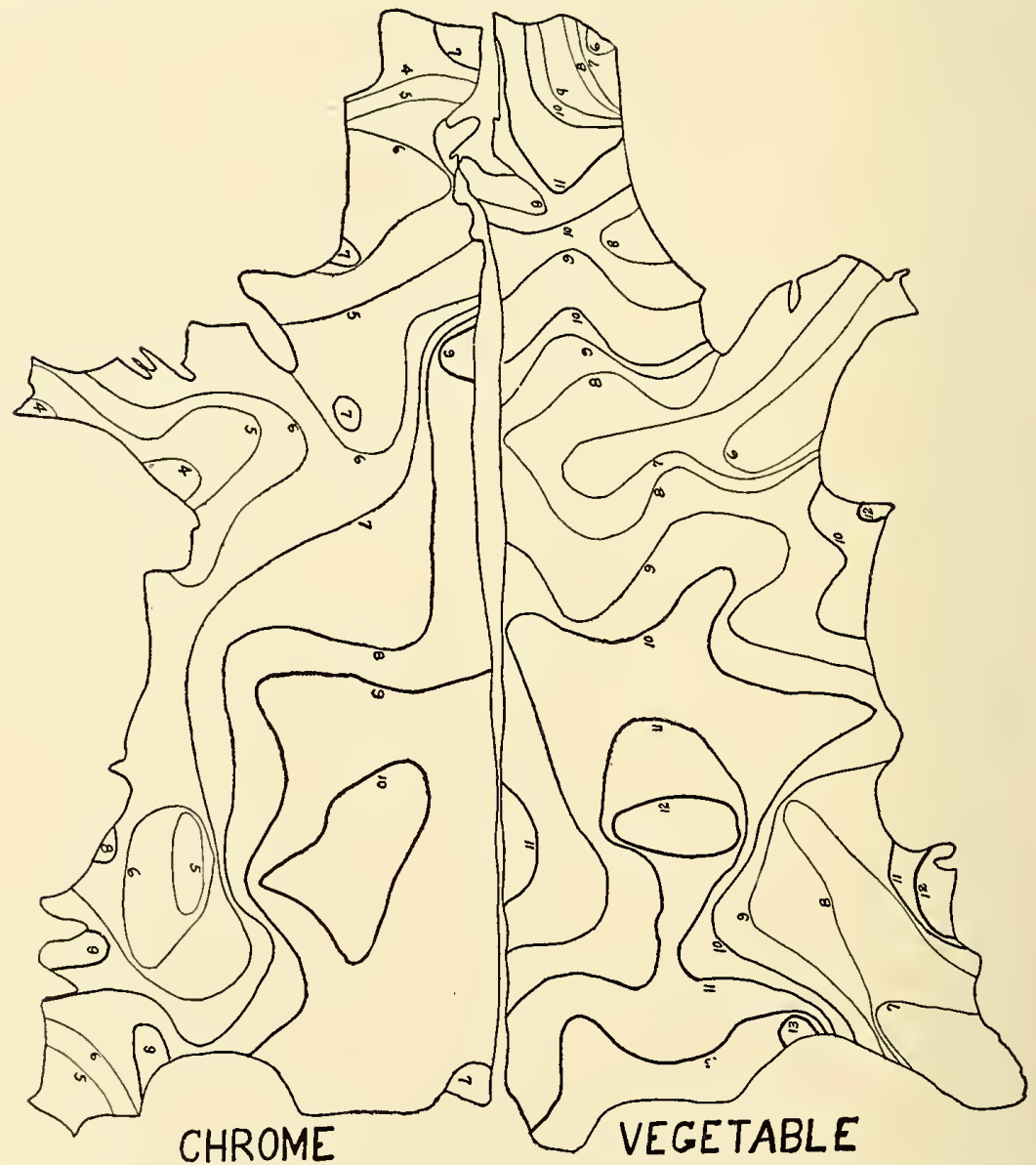

FIG. 9.-Topographical illustration of the difference and variation in thickness of a side of chrome tamed sole leather and a side of vegetable tanned. sole leather, both tanned from the samc hide. Series 2

8.0 irons and for the vegetable soles 9.9 irons, showing approximately 25 per cent greater thickness for the vegetable soles.

3 The iron is a unit of measure used in the trade to designate the thickness or gauge of sole leather and is equal to approximately $1 / 2$ millimeter in the metric seale, and is equal to $1 / 48$ inch in the English scale. 
A study was also made of the rariation in thickness of these two units by marking them with parallel lines 4 inches apart both in the lengthwise and crosswise directions. The thickness at each intersection point was measured and from these results a topographical representation showing approximately the different thickness areas was prepared which is shown in Figure 9. The greater thickness of the regetable leather throughout is plainly evident. It also indicates that the maximum thicknesses for the chrome leather are spread over a greater area, the effect of which would be to require less skiving of the individual sole in preparing it for attachment to the shoe.

Figure 10 shows the comparative thicknesses for the soles cut from similar hide locations after they had been skived to a uniform thickness and were ready for test. Aside from its value in showing the thickness comparison, this chart also demonstrates that both sides of the hide had similar thickness variations. Any one curve represents the thickness of soles cut from the backbone to the belly edge of the bend. It will be observed that any two curves representing the thicknesses of the two leathers cut from the same location on the

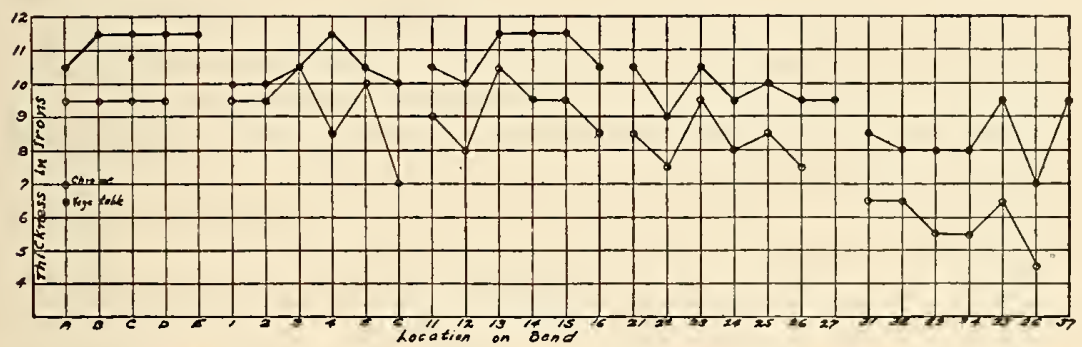

FIG. 10.-Comparative thickness of soles for different locations on the hide. Series 2

two sides of the same hide have, in general, similar maximum and minimum points.

It has been shown above that natural chrome leather is thinner than vegetable leather when both are prepared from hides of equal original thickness. It is often necessary to produce chrome sole leather of equal substance, and this may be accomplished by the addition of certain filling materials, as is demonstrated by comparing the a verage thicknesses of the leathers tested in series 3. Both were tanned from the same hides, and the a verage thickness of the regetable soles was 8.1 irons, while for the filled chrome soles it was 8.2. One of the functions of the filling materials, then, is to increase the thickness of the leather. When it is desired to secure thick, natural chrome sole leather it is necessary to use as raw material very heavy hides, such as are typical of the bull and water buffalo. The thickness of such leather will run from 9 to 11 irons.

(c) Comparative Areas.-Since the number of soles that may be cut from any leather unit depends on the surface area, observations were made to show the comparative yield in area for the two tan- 
nages upon leathers tanned from the same hides. The leather tested in series 2, Figure 4, and in series 3, Figure 5, represents such material. A glance at these photographs will show that the chrome unit in each case has a smaller area than the vegetable unit. In each case the two leather units from the same hide were photographed and then by means of a planimeter an approximate area ratio was obtained. The results are contained in Table 5.

TABLE 5.-Comparatice area of chrome and regetable tanned leather

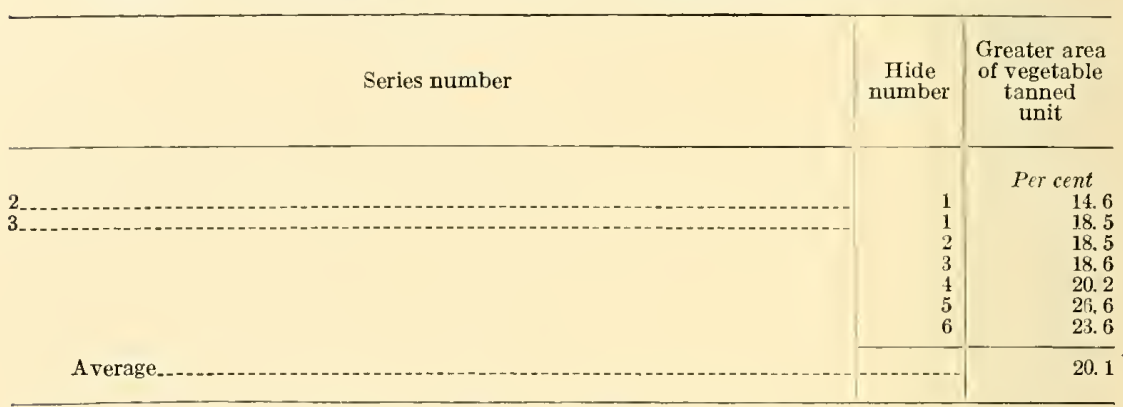

This result can be considered as only approximate since it is evident from the photographs that the hides originally were not cut exactly in half before tanning. It does appear safe to state, however, that a hide tanned by the chrome process will yield from 10 to 12 per cent less area in leather than if tanned by the regetable process.

\section{CONCLUSIONS}

The results of this investigation justify the following definite conclisions:

1. Natural and paraffin filled chrome sole leather will wear approximately twice as long as regetable sole leather per unit of thickness.

2. Natural chrome will give the longest wear, paraffin filled ranking next, and that additionally filled with mineral material ranking third, the latter, however, wearing about one-third longer than regetable.

3. Although vastly superior in wearing quality by comparison with the vegetable leather, chrome sole leathers, in general, have disadvantages in appearance, lack of firmness, lack of water resistance, and tendency to slip which can be only partly overcome by the addition of certain filling materials. Whereas such chrome leathers have a limited application, the field of usefulness could be broadened with consequent economic advantage to the public by reason of the greater wear obtainable, should a method of preparing chrome leather be developed which would give it more nearly the desirable qualities of the regetable leathers.

Washington, November 18, 1924. 